LEE LILLARD* AND RoBERT J. WILLIS**

University of Michigan

\title{
Patterns of Intergenerational Transfers in Southeast Asia
}

This article explores motivations for intergenerational exchanges of time and money using data from Indonesia. The extent of exchange and underlying motivations differ across families but substantial evidence supports the theory that transfers within families serve as insurance for family members. The results also suggest that between some parents and children money is exchanged for time. Additionally, some evidence is consistent with the idea that parents pay for their children's education partly as a loan that is later repaid. The authors compare their results to those that they obtained previously for Malaysia using similar data and methods. The findings regarding motivations for transfers are remarkably similar across the two countries.

The family is a critical social institution in providing support to its members. The effects on this support of changes in family structures, such as longer life expectancies and greater diversity of

Department of Sociology, University of California-Los Angeles. 264 Haines Hall. Los Angeles, CA 90095-1551 (efranken@soc.ucla.edu).

*With great sadness we note that Lee Lillard died on December 2, 2000. He was a Professor of Economics at the University of Michigan and a Senior Research Scientist at the Institute for Social Research.

\footnotetext{
**Department of Economics and the Institute for Social Research, University of Michigan. 426 Thompson Street. Ann Arbor, MI 48104.
}

Key Words: aging, Asia, exchange, family, transfers. family forms, are hotly debated in academic and policy circles (Bengtson, 2001). One function families provide is the transfer of resources-both time and money-among family members. Scientific inquiry into transfers across generations encompasses macro and micro perspectives. A considerable literature addresses the evolution of transfer patterns as societies industrialize, pass through the demographic transition, and develop more sophisticated public and private financial services (Cowgill \& Holmes, 1972; Goode, 1963; Parsons, 1943; Ruggles, 1987; Willis, 1982). Other research models decision making within families to generate predictions about transfer behavior (Becker, 1974, 1991; Becker \& Tomes, 1976; Cox, 1987).

Complementing theoretical work, empirical analyses consider how characteristics of parents and children are related to transfer behavior. In most developing countries families are the primary source of support for aging individuals. The policy salience of family transfer behavior has increased in the developing world as the share of the elderly population rises but government and private mechanisms of old age support remain limited. Families as a source of old age support have received particular attention in Asia, where populations are aging rapidly (Hermalin, 1997; Kinsella, 2000; Knodel \& Debavalya, 1997; Knodel, Friedman, Ahn, \& Cuong, 2000; Martin, 1989).

We examine interhousehold transfers between adult children and their parents in Indonesia. The analyses test hypotheses of models of motives for 
intergenerational transfers. To fully explore these models, one must consider the overall process of exchange rather than limiting analysis to a narrow demographic group, a discrete type of support, or transfers in one direction (Hogan, Eggebean, \& Clogg, 1993). We consider giving and receiving, of time and money, from the perspectives of parents and adult children. Thorough analysis also requires detailed data on both generations. We use extremely rich data from the Indonesia Family Life Survey.

We set the stage for our analysis of Indonesia by describing results obtained for Malaysia (Lillard \& Willis, 1997b). The comparison is interesting because the countries are sufficiently similar to suggest common patterns of transfers and underlying motivations for them. Moreover, because the data from the two countries are almost identical, the comparison is relatively free from the differences in data set content and methods that often hinder cross-country comparisons.

\section{THEORIES}

Several family theories address motivations for family transfers and generate hypotheses regarding the empirical relationships of characteristics of parents and children to transfers between them. In a model of the family developed by Becker (1974, 1991) each household's head allocates resources among family members so that no one can be made better off without making someone else worse off. Some family members may receive more resources than they provide. The head may choose to transfer resources to needier family members because of altruism. In the context of transfers from parents to children, the more altruistic the head, the more the head will finance investments in children without expecting repayment (Becker \& Tomes, 1976). Altruism may also lead children to transfer resources to their aging parents, particularly if parents have instilled a strong sense of filial responsibility in their children (Lee, Parish, \& Willis, 1994).

A key distinction between altruism and other models of transfers is that in an altruistic system needy family members should receive over their lifetime more transfers than they provide. Unfortunately, the lack of data on net transfers over the life course makes this prediction difficult to test. Other models emphasize a quid pro quo aspect to transfers (Bernheim, Shleifer, \& Summers, 1985). One such model emphasizing the long-term role of transfers posits that transfers among kin pro- vide a source of insurance against risk. Family members transfer resources to help one another in times of need. If risks across family members are not perfectly correlated, when one relative hits a rough spot (say a crop failure), odds are that another relative will be in a position to offer assistance.

If altruism or insurance motivates transfers, then at a point in time characteristics indicative of need (such as poor health or widowhood), should be positively associated with the receipt of transfers. Our empirical work tests these predictions. The altruism and insurance models also predict that transfers to and from an individual should fluctuate with short-term income. We use retrospective information on labor income to examine whether transfer behavior is sensitive to recent earnings.

Another model with a quid pro quo element focuses on the shorter term, hypothesizing that transfers reflect an exchange of money for time (Cox, 1987). For example, elderly parents may care for grandchildren in return for money from adult children, or able-bodied adult children may perform chores for their parents in return for money. Our data are unusual in that they include information about provision and receipt of time, as well as money and goods. We therefore examine whether the provision of money is related to the receipt of time, and vice versa.

One of the oldest models for transfers between parents and children views family as a source of capital. In a traditional society, children offer the only long-term mechanism of saving for old age. Couples have children with the expectation that children will provide for them in later life (see Willis, 1980 and references therein). Children have an incentive to provide old age security for their parents because parents control land and family businesses on which children rely for income. Moreover, children who support their parents in old age may view themselves as setting a precedent for their own children to follow (Ikkink, Tilburg, \& Knipscheer, 1999; Stark, 1995).

Economic development destabilizes this system. As financial services develop, individuals have access to savings methods other than children and so fertility declines. Industrialization and modernization encourage individualism, provide temptingly lucrative opportunities outside family businesses, and strengthen ties between husbands and wives, to the potential detriment of ties between parents and adult children. In this model the net flow of resources over the life course, ini- 
tially from young to old, reverses over several generations (Caldwell, 1976; Goode, 1963).

Although this description is intuitively compelling, evolutionary theory, formal demography, and a number of empirical findings suggest that, on balance, net resources flow from old to young in all but the most developed societies (Kaplan, 1994; Lee, 2000; Preston, 1982; Stecklov, 1997). Moreover, the description does not fit the experiences of several East Asian countries, which in the 1980s were characterized by simultaneously high savings rates, major improvements in children's living standards relative to their parents', and elderly reliance on transfers from family members.

Family may also provide capital in contexts where the expected earnings of the well-educated are rising rapidly. Children's educational needs occur at ages when they have to rely on their parents. In turn children may repay parents for educational loans through support during old age. If they expect to share in the resulting benefits down the road, it may behoove couples to loan children money for school to maximize the joint lifetime wealth of themselves and their children.

If a borrower-lender arrangement for financing education motivates transfers, then transfers should be related to children's enrollment status and educational attainment. We test for associations between schooling outcomes and transfers to assess the degree to which family operates as a capital market. In a strict borrower-lender relationship, neither the lender's characteristics nor the borrower's economic circumstances should affect repayment, although loans between parent and child may be more flexible.

Models in which family functions as a capital market for old age support or educational loans are closely related to the model of family as a source of insurance. Each emphasizes the quid pro quo nature of transfers between family members and relies on variation across family members in the timing of their needs for money. Each requires family members to comply with a system mandating behavior that at times is inconsistent with immediate self-interest (Willis, 1982). Compliance may be encouraged through anticipation of inheritance and by instilling loyalty and responsibility during childhood (possibly reinforced by community norms; Burr \& Mutchler, 1999; Lee et al., 1994; Willis, 1982).

\section{BACKGROUND}

The models suggest that transfer patterns are shaped by a country's recent economic and de- mographic history, as well as by underlying norms regarding relationships between adult children and their parents. Comparison of two countries resembling each other in these respects allows us to assess whether commonalities in transfer patterns emerge across similar settings. Malaysia and Indonesia are well suited for such a comparison. In this section, we review the two countries' similarities and evidence regarding transfer motivations in Malaysia, describe the Indonesian context, and discuss the factors we consider in examining motivations for transfers.

Indonesia and Malaysia are geographic and cultural neighbors. Malays constitute the majority ethnographic group in both countries and in fact the national languages of Indonesia and Malaysia originate from a common source: a trading language used for centuries by groups on either side of the Straits of Malacca (Sievers, 1974, p. 15). In both countries Islam is the predominant religion. Malaysia's economy developed earlier than Indonesia's and differences in economic status remain: In the early 1990s per capita GDP was three times higher in Malaysia (Jones, 1994, p. 19; World Bank, 1997).

Our earlier work on Malaysia (Lillard \& Willis, 1997b) used data from the 1988 Malaysian Family Life Survey. The structures of the Malaysia Family Life Survey and Indonesia Family Life Survey transfer data are extremely similar and the same statistical approach is employed.

The results from Malaysia provide support for three theories of transfers: parental repayment for school loans, exchange of money for time, and insurance against risk. Relationships consistent with the parental repayment hypothesis are especially strong. Children's educational attainment is positively associated with the likelihood and the amount of transfers that parents receive from their children. Moreover, consistent with a borrowerlender relationship, parental income levels do not affect transfers received from children. Results from Malaysia are also strongly consistent with the exchange hypothesis. Couples are more likely to transfer money to their parents - and to transfer larger amounts-when the parents have provided help in the form of time. Similarly, couples are more likely to receive transfers of money from their parents when they have provided time to their parents. Finally, the analysis of Malaysia supports the theory that transfers provide insurance within families. Transfers to parents from couples increase in likelihood or in value when parents are older, in poor health, or widowed. 
Similarly, transfers are related to income levels and are sometimes more responsive to current than to long-term income.

Though Malaysia began the transition to a modern economy earlier, Indonesia's socioeconomic progress since the mid-1960s is impressive. Between 1967 and 1997 Indonesia's per capita GDP rose by an annual average of almost $5 \%$. Over the same period Indonesia achieved nearly universal primary school enrollment and substantial increases in secondary school enrollment. By the mid-1990s life expectancy surpassed 60 years and the total fertility rate had fallen to 2.7.

By the 1990s Indonesia was no longer a traditional high fertility society in which adult children's livelihoods largely depend on their parents' land. Traditionally, however, family has been the primary source of old age support. Studies document strong economic ties between adult children and their elderly parents (Chen \& Jones, 1989; Evans, 1990; Hugo, 1992; Rudkin, 1993; Wirakartakusumah, Sirait, \& Hidayat, 1997). A 1986 survey of elderly Javanese found that $50 \%$ of male respondents and $70 \%$ of female respondents reported relying on children or grandchildren "for at least some income" (Hugo, 1992). Evidence from Yogyakarta province suggests that monetary transfers are targeted to family members who are older, in poor health, or (in urban areas) unemployed (Ravallion \& Dearden, 1988).

In Indonesia strong ties between parents and adult children are attributed to social norms that deem children responsible for their elderly parents' welfare (Geertz, 1961; Wirakartakusumah, 1998). The predominance of these norms emerges in a survey of experts in adat (traditional) law conducted in the Indonesia Family Life Survey. Over $99 \%$ of respondents reported that traditional law obligates children to care for their older parents, and 97\% said that when parents live with one child, other children should provide additional assistance. Responsibility for one's aging parents is also an important tenet of Islam (Mahmood, 1992).

The factors we consider in our analyses of transfer behavior derive from the models discussed above. The dependent variables and the statistical methods are discussed in the next section. Our analysis considers transfers from the perspective of couples in two familial roles: as parents and as children.

We begin by discussing couples in their role as parents of adult children. To test the parental repayment hypothesis, we carefully consider the role of children's schooling. Measures of children's current enrollment status allow us to test whether parents help finance their children's education by providing transfers while children are still in school. We also include measures of children's education in models of monetary transfers that parents receive from their children (the number of children currently in school and the numbers who are high-school and college graduates, respectively). These variables reveal whether transfer receipts increase with children's educational attainment. The old age security model predicts that transfers from children rise as couples age. Accordingly we include the ages of the husband and the wife in models where the outcome is the couple's receipt of transfers from children. Finally, we include controls for whether the wife works and the earnings of the husband and wife because the insurance theory suggests that higher incomes should decrease receipt of transfers from children and increase transfers to children.

We now turn to couples in their role as children of older parents. In keeping with the parental repayment hypothesis we include variables for the child's level of education, which allows us to test whether transfers rise with educational attainment. To assess whether transfers appear to function as insurance against hard times, we include measures of long-run earnings based on retrospective data and recent earnings. The long-run earnings measure consists of age-adjusted mean monthly earnings over time; the short-term earnings measure consists of the deviation of current monthly earnings from long-term earnings. The insurance hypothesis suggests that transfer behavior should be more sensitive to short-term earnings than to longterm earnings. As a measure of the couple's need for parental assistance in the form of time, we include measures of the number of small children in the household. Other measures of need reflect parents' characteristics and include age and health status and whether the mother is a widow. To test the theory of exchange of money for time, we examine whether the couple's provision of money to parents is sensitive to whether parents provided help in the form of time and whether couples who receive money from their parents provided help to them in the form of time. In each specification from the perspective of couples as children, we include controls for the work status of wife and her earnings.

\section{Data}

Our empirical analysis uses data from the 1993 Indonesia Family Life Survey to investigate trans- 
fer behavior between parents and adult children. The survey was conducted in 7,224 households and represents $83 \%$ of the population. Individuals 15 and older were asked to answer extensive questions about the characteristics of their children 15 and older living outside the household and about the provision and receipt of money, goods, and services to and from these children over the 12 months prior to the interview. Similar questions were posed about noncoresident parents.

We analyze the transfer behavior of married couples from two perspectives. We consider couples in their roles as parents, using information from couples with at least one adult child out of the household. A total of 2,349 couples have at least one surviving child 15 or older who does not reside in the household. We also consider couples in their roles as adult children with aging parents, using information for couples in which either the husband or the wife has a surviving parent. For 2,688 couples the wife has a surviving parent, for 2,315 couples the husband has a surviving parent, and for 1,688 couples both the husband and the wife have a surviving parent. Couples with both a noncoresident adult child and a noncoresident parent contribute to the analyses from both perspectives (928 couples in total).
Table 1 presents descriptive statistics on transfers from the perspectives of couples as parents (Panel A) and as adult children (Panel B). The information is based on respondents' answers to questions about whether, in the past year, they had provided any help or assistance in the form of money, goods, or time helping with chores, errands, childcare, or care during illness or because of poor health. Respondents who answered affirmatively were queried as to the value of money or goods provided. Parallel questions were posed with respect to receipt of help and the monetary value of help received.

Beginning with Panel A, about $44 \%$ of couples transfer money to their noncoresident children and $55 \%$ of couples receive money from these children. Some couples simultaneously make transfers to and receive transfers from adult children. This result is consistent with ethnographic work in Java showing that parents subsidized their daughters who left home to work in factories but the young women in turn used their wages to buy clocks, dishes, and radios for their parents (Wolf, 1991). With respect to values, the average amount couples transfer to children (in the event of positive transfers) is about equal to the average amount couples receive from children. We also calculate

Table 1. Sample Sizes and Description: Any Transfers and Amount (\$U.S.)

Panel A. Couples as Parents: Transfer With Noncoresident Children Age 15 or Over, as a Group

$\% \quad$ Amount $^{\mathrm{a}}$

\begin{tabular}{|c|c|c|c|c|}
\hline & $\%$ & Amount $^{\mathrm{a}}$ & & \\
\hline \multicolumn{5}{|l|}{ Money transfers } \\
\hline To all children & 43.5 & \multicolumn{3}{|l|}{287.13} \\
\hline From all children & 55.2 & \multicolumn{3}{|l|}{285.83} \\
\hline From children's/couple's household income ${ }^{b}$ & 3.0 & & & \\
\hline \multicolumn{5}{|l|}{ Time transfers } \\
\hline To children & \multicolumn{4}{|l|}{5.3} \\
\hline From children & \multicolumn{4}{|l|}{6.3} \\
\hline Number of couples with any eligible children & \multicolumn{4}{|l|}{2349} \\
\hline \multicolumn{5}{|c|}{ Panel B. Couples as Adult Children: Transfers With Noncoresident Parents } \\
\hline & \multicolumn{2}{|c|}{ Wife's Parents } & \multicolumn{2}{|c|}{ Husband's Parents } \\
\hline & $\%$ & Amount $^{\mathrm{a}}$ & $\%$ & Amount ${ }^{\mathrm{a}}$ \\
\hline \multicolumn{5}{|l|}{ Money transfers } \\
\hline Money to parents & 53.5 & 188.10 & 59.9 & 121.41 \\
\hline \multicolumn{5}{|l|}{ Money to parents'/couple's household income ${ }^{b}$} \\
\hline Only wife's/husband's parents eligible & 1.4 & & 1.7 & \\
\hline Both wife's/husband's parents eligible & 1.5 & & 1.7 & \\
\hline Money from parents & 27.9 & 93.27 & 20.8 & 165.97 \\
\hline \multicolumn{5}{|l|}{ Time transfers } \\
\hline Time to parents & 6.3 & & 7.4 & \\
\hline Time from parents & 3.9 & & 3.1 & \\
\hline Number of couples with eligible parent & 2688 & & 2315 & \\
\hline Number of couples with both parents eligible & 1688 & & & \\
\hline
\end{tabular}

${ }^{\text {a }} 1$ U.S. $=$ about 2,100 Indonesian rupiah in 1993. Does not include zero values. 'Includes zero amounts. 
monetary transfers as a share of household income. The transfers couples receive from their children account for only about $3 \%$ of their total household income (this figure includes zero values for couples receiving no transfers).

Transfers of time between parents and noncoresident children are much less frequent than are transfers of money. Only $6.3 \%$ of parents mention that noncoresident children spend time helping them and only $5.3 \%$ of parents mention that they spend time helping their noncoresident children.

From the perspective of couples as adult children (Panel B), transfers of money to parents are far more common than receipt of money from parents. Over half of all couples transfer money to the wife's parents and a full $60 \%$ transfer money to the husband's parents, but only about one quarter receive money from the wife's parents, and only one fifth receive money from the husband's parents.

The relative and absolute amounts of money given and received differ depending on whether the parents are those of the wife or the husband. On average, the amounts that couples transfer to the wife's parents are about two times higher than the amounts that couples receive from the wife's parents. In contrast, the amounts that couples transfer to the husband's parents are lower than the amounts that couples receive from the husband's parents. It appears that couples are less likely to transfer money to the wife's parents than to the husband's parents but when they do transfer money to the wife's parents they transfer relatively larger amounts. Also, although couples are less likely to receive transfers from the husband's parents than from the wife's parents, when they do receive transfers they receive relatively larger amounts. The money couples transfer to their parents represents only $1 \%-3 \%$ of their total household income.

Transfers of time between couples and their parents are infrequent. Only 3\%-7\% of couples report transfers of time and they are more likely to provide time than to receive it. Thus, whether one considers a couple as the parents of noncoresident children, or as the adult children of noncoresident parents, transfers of time are much less frequent than transfers of money. The low frequency of time transfers does not appear to be driven by the lack of physical opportunity. Over half of couples report seeing their parents at least once a week, and almost $60 \%$ of couples see at least one noncoresident child at least once a week. About $70 \%$ of couples live within the same ad- ministrative area (roughly equivalent to a county) as their parents, and about $60 \%$ of couples live within the same administrative area as one of their noncoresident children. The infrequency of time transfers suggests that the theory that the primary motivation for transfers is a desire to exchange money for time (or vice versa) does not hold for more than a small fraction of the households involved in transfers. We now turn to the multivariate analyses. The results provide more insights into motivations because they reveal how characteristics of parents and children are related to transfers.

\section{RESULTS}

\section{Couples as Parents}

We estimate five equations to characterize transfers, from the parents' perspective, with their noncoresident children 15 and older. These equations correspond to:

any transfer of money to children (MTC) and $\log$ amount if greater than $0\left(\ln \mathrm{A}_{\mathrm{MTC}}\right)$

any transfer of money from children (MFC)

and $\log$ amount if greater than $0\left(\ln \mathrm{A}_{\mathrm{MFC}}\right)$

any transfer of time from children (TFC)

A probit function indicates whether transfers of money (MTC, MFC) or time (TFC) occurred:

$$
\mathrm{T}= \begin{cases}1 & \text { if } \alpha^{\prime} \mathrm{X}+v>0 \\ 0 & \text { otherwise }\end{cases}
$$

When monetary transfers ( $\ln \mathrm{A}_{\mathrm{MTC}}, \ln \mathrm{A}_{\mathrm{MFC}}$ ), are greater than 0 , the amount transferred is given by:

$$
\ln A=\beta^{\prime} X+\mu
$$

The probit and the log amount equations are estimated separately. Estimating the equations simultaneously (joint pairwise) using functional form for identification had no impact on the substantive results, nor were any of the estimated correlations statistically significant.

The determinants of transfers from couples to their adult children are presented in Table 2. Clearly, parents with children in school are more likely to transfer resources to their offspring. The numbers of children in high school and in college are strongly and positively correlated with both the occurrence and the amount of transfers.

The labor market decisions and successes of husbands and wives are also strongly associated with transfers to children. As the husband's earnings rise, so too does the amount transferred. The 
Table 2. Couples as Parents: Money Transfers to all Adult Noncoresident Children

\begin{tabular}{lcc}
\hline & Any Money & Log Amount \\
\hline Intercept & $-0.433^{*}$ & 0.202 \\
& $(0.209)$ & $(0.425)$ \\
Number of children in high school & $0.872^{* *}$ & $0.704^{* *}$ \\
& $(0.090)$ & $(0.096)$ \\
Number of sons in college & $0.854^{* *}$ & $1.227^{* *}$ \\
Number of daughters in college & $(0.134)$ & $(0.166)$ \\
Wife's education & $0.503^{* *}$ & $1.180^{* *}$ \\
Husband's education & $(0.149)$ & $(0.228)$ \\
& 0.018 & 0.036 \\
Log wife's monthly earnings & $(0.010)$ & $(0.021)$ \\
Wife not working & $0.041^{* *}$ & $0.065^{* *}$ \\
Log husband's monthly earnings (current) & $(0.008)$ & $(0.018)$ \\
& 0.035 & $0.137^{* *}$ \\
& $(0.023)$ & $(0.051)$ \\
\hline
\end{tabular}

Note: $n=2,349$. Standard errors are in parentheses.

$* p<.05 . * * p<.01$.

probability of a transfer is reduced when the wife does not work. When she does work, the amount transferred rises with her earnings. Thus mothers as well as fathers are an important source of financial support for the educational attainment of their children.

Table 3 presents the models of money transfers to couples from their adult children (Columns 1 and 2). As with monetary transfers in the reverse direction, children's enrollment status is strongly correlated with the transfers parents receive. Specifically, the number of children currently in school has a large and significant negative impact on the likelihood that couples receive transfers from children. When a transfer does take place, however, the number of children in school has a significant positive impact on the amount transferred. Some couples with children in school probably receive relatively generous contributions from other children who are helping to subsidize their siblings' education. Qualitative research documents this phenomenon on Java, where young women who have left home to work send money to help their younger siblings stay in school (Wolf, 1991).

The number of children who have completed school is positively related both to the occurrence of transfers to the couple and to the amount transferred. Educational attainment of children is not related to whether couples receive a transfer but it is a strong predictor of the amount transferred. Controlling for the total number of children, as the number of children who have attained relatively high levels of schooling rises, the value of transfers the couples receive rises as well. Consistent with the repayment model of transfers, parents whose adult children are well-educated receive more resources from their offspring than parents whose children are less well-educated. Because we cannot control for children's income levels, however, the results for educational attainment may partially reflect higher economic status of better educated children (we address this concern in the next section).

The labor force experiences of the couples themselves are also significant predictors of whether they receive transfers from their children. As the earnings of either the wife or the husband rise, the chance that the couple receives money from their adult children declines. This result is consistent with the prediction of the insurance theory. When a couple's economic situation makes transfers less necessary, they are in fact less likely to occur.

The correlations of the couples' characteristics with the amount of transfers received (for those who receive anything) are somewhat different from the correlations with whether a transfer occurs. The level of the wife's education and the level of the husband's earnings are positively correlated with the amount that parents receive from their children. These results may arise because of positive correlations between father's and childrens' earnings and between mother's human cap- 
Table 3. Perspective of Couples as Parents: Money and Time Transfers From all Adult NonCoresident CHILDREN

\begin{tabular}{|c|c|c|c|}
\hline & Any Money & Log Amount & Any Time \\
\hline \multicolumn{4}{|l|}{ Children's characteristics (number) } \\
\hline In school & $\begin{array}{c}-0.180 * * \\
(0.049)\end{array}$ & $\begin{array}{l}0.231 * * \\
(0.087)\end{array}$ & $\begin{array}{c}0.147 \\
(0.092)\end{array}$ \\
\hline Completed school & $\begin{array}{l}0.152^{* * *} \\
(0.021)\end{array}$ & $\begin{array}{l}0.156^{* * *} \\
(0.029)\end{array}$ & $\begin{array}{c}0.027 \\
(0.032)\end{array}$ \\
\hline High-school graduates & & & $\begin{array}{c}0.001 \\
(0.040)\end{array}$ \\
\hline High-school graduate sons & $\begin{array}{c}0.032 \\
(0.038)\end{array}$ & $\begin{array}{l}0.233^{* *} * \\
(0.044)\end{array}$ & - \\
\hline High-school graduate daughters & $\begin{array}{c}0.001 \\
(0.038)\end{array}$ & $\begin{array}{l}0.251^{* *} \\
(0.050)\end{array}$ & - \\
\hline College graduates & & & $\begin{array}{c}-0.026 \\
(0.095)\end{array}$ \\
\hline College graduate sons & $\begin{array}{c}0.010 \\
(0.086)\end{array}$ & $\begin{array}{l}0.306^{* *} \\
(0.109)\end{array}$ & \\
\hline College graduate daughters & $\begin{array}{c}0.146 \\
(0.104)\end{array}$ & $\begin{array}{c}0.310^{*} \\
(0.154)\end{array}$ & \\
\hline \multicolumn{4}{|l|}{ Couple's characteristics } \\
\hline Wife's education & $\begin{array}{c}0.002 \\
(0.011)\end{array}$ & $\begin{array}{l}0.053 * * \\
(0.016)\end{array}$ & $\begin{array}{r}-0.029 \\
(0.017)\end{array}$ \\
\hline Husband's education & $\begin{array}{c}-0.026 * * \\
(0.010)\end{array}$ & $\begin{array}{c}0.019 \\
(0.016)\end{array}$ & $\begin{array}{c}0.012 \\
(0.017)\end{array}$ \\
\hline Wife's age & $\begin{array}{l}0.012 * * \\
(0.004)\end{array}$ & $\begin{array}{c}-0.005 \\
(0.006)\end{array}$ & $\begin{array}{c}0.014^{*} \\
(0.005)\end{array}$ \\
\hline Husband's age & $\begin{array}{c}0.001 \\
(0.001)\end{array}$ & $\begin{array}{c}-0.001 \\
(0.002)\end{array}$ & $\begin{array}{c}-0.001 \\
(0.002)\end{array}$ \\
\hline Log wife's monthly earnings & $\begin{array}{c}-0.065^{* * *} \\
(0.024)\end{array}$ & $\begin{array}{c}0.003 \\
(0.033)\end{array}$ & $\begin{array}{c}0.062 \\
(0.035)\end{array}$ \\
\hline Wife not working & $\begin{array}{c}0.063 \\
(0.066)\end{array}$ & $\begin{array}{c}0.189 \\
(0.099)\end{array}$ & $\begin{array}{c}-0.650 * * \\
(0.117)\end{array}$ \\
\hline Log husband's earnings (current) & $\begin{array}{c}-0.071^{* *} \\
(0.024)\end{array}$ & $\begin{array}{l}0.136 * * \\
(0.039)\end{array}$ & $\begin{array}{c}-0.098^{*} \\
(0.044)\end{array}$ \\
\hline Intercept & $\begin{array}{c}0.067 \\
(0.289)\end{array}$ & $\begin{array}{c}1.476 \\
(0.487)\end{array}$ & $\begin{array}{c}-1.856 \\
(0.476)\end{array}$ \\
\hline
\end{tabular}

Note: $n=2,349$. Includes controls for the number of children living with the parents, whether a son is present, and whether a daughter is present. Standard errors are in parentheses.

$* p<.05 . * * p<.01$.

ital and children's earnings. Economically successful parents may produce economically successful children, who in turn can afford to transfer relatively more generous amounts to their parents.

The third column of Table 3 considers transfers of time. Characteristics of couples affect the chance that their children will provide services to them more than do the characteristics of the children themselves. Transfers of time from children are less likely when the wife is not working or when the husband's earnings are high. None of the indicators of children's educational accomplishments are significantly related to whether couples receive transfers of time. This result lends support to the repayment hypothesis in that children's education is specifically related only to monetary transfers.

\section{Couples as Adult Children}

We turn now to the perspective of couples as adult children, for which a larger number of transfer options exist. Couples can make transfers (of time or money) to the wife's parents or to the husband's parents, and couples can receive transfers (of time or money) from the wife's parents or from the husband's parents. We focus on the following (12) types of transfers:

Any money to the wife's parents and Log amount if greater than zero

Any money to the husband's parents and Log amount if greater than zero

Any time from the wife's parents and Any time from the husband's parents

Any money from the wife's parents and Log amount if greater than zero 
Table 4. Standard Deviations and Correlations (Standard ERrors) of Family Components in Transfers

\begin{tabular}{|c|c|c|c|c|c|c|}
\hline & $\begin{array}{l}\text { Any Money } \\
\text { to Parents }\end{array}$ & $\begin{array}{l}\text { Amount } \\
\text { to Parents }\end{array}$ & $\begin{array}{l}\text { Any Time } \\
\text { From } \\
\text { Parents }\end{array}$ & $\begin{array}{c}\text { Any Money } \\
\text { From } \\
\text { Parents }\end{array}$ & $\begin{array}{l}\text { Amount } \\
\text { From } \\
\text { Parents }\end{array}$ & $\begin{array}{l}\text { Any Time } \\
\text { to Parents }\end{array}$ \\
\hline Any money to parents & $\begin{array}{l}0.706 * * \\
(0.059)\end{array}$ & - & & & & \\
\hline Amount of money to parents & $\begin{array}{c}0.063 \\
(0.129)\end{array}$ & $\begin{array}{l}0.680 * * \\
(0.048)\end{array}$ & - & & & \\
\hline Any time from parents & $\begin{array}{c}0.429 \\
(0.228)\end{array}$ & $\begin{array}{c}0.195 \\
(0.222)\end{array}$ & $\begin{array}{l}0.688 * * \\
(0.178)\end{array}$ & - & & \\
\hline Any money from parents & $\begin{array}{l}0.304 * * \\
(0.075)\end{array}$ & $\begin{array}{c}-0.338^{* * *} \\
(0.080)\end{array}$ & $\begin{array}{l}0.708 * * \\
(0.126)\end{array}$ & $\begin{array}{l}0.573 * * \\
(0.070)\end{array}$ & - & \\
\hline Amount of money from parents & $\begin{array}{c}-0.618 * * \\
(0.111)\end{array}$ & $\begin{array}{l}0.999 * * \\
(0.092)\end{array}$ & $\begin{array}{l}0.032 \\
(0.1761)\end{array}$ & $\begin{array}{c}0.084 \\
(0.279)\end{array}$ & $\begin{array}{l}0.639 * * \\
(0.166)\end{array}$ & - \\
\hline Any time to parents & $\begin{array}{l}0.393 * * \\
(0.081)\end{array}$ & $\begin{array}{c}0.026 \\
(0.086)\end{array}$ & $\begin{array}{l}0.999 * * \\
(0.101)\end{array}$ & $\begin{array}{c}0.184 \\
(0.182)\end{array}$ & $\begin{array}{c}0.227 \\
(0.236)\end{array}$ & $\begin{array}{l}0.927 * * \\
(0.124)\end{array}$ \\
\hline
\end{tabular}

Note: $n=1,688$. All equations estimated jointly.

$* p<.05 . * * p<.01$.

Any money from the husband's parents and Log amount if greater than zero

Any time to the wife's parents and Any time to the husband's parents

Data on transfers to two sets of parents allows use of a parametric within couple estimator to account for heterogeneity across couples in propensity to transfer. The occurrence of transfers of money to the wife's parents is modeled as a probit:

$$
\begin{aligned}
& \operatorname{MTP}_{w} \\
& = \begin{cases}1 & \text { if } \alpha^{\prime}{ }^{\prime} X_{w}+\alpha_{w 2} \operatorname{TFP}_{w}+\xi+v_{w}>0 \\
0 & \text { otherwise }\end{cases}
\end{aligned}
$$

where TFP is an indicator of whether the wife's parents provided transfers of time and is included to test the exchange (of money for time) hypothesis.

When transfers of money are greater than 0 , the amount of money transferred is given by:

$$
\ln \mathrm{A}_{\mathrm{MTP}_{\mathrm{w}}}=\beta^{\prime}{ }_{\mathrm{w} 1} \mathrm{X}_{\mathrm{w}}+\beta_{\mathrm{w} 2} \mathrm{TFP}_{\mathrm{w}}+\lambda+\mu_{\mathrm{w}}
$$

The occurrence of transfers of time from the wife's parents is also modeled with a probit function:

$$
\operatorname{TFP}_{\mathrm{w}}= \begin{cases}1 & \text { if } \alpha^{\prime}{ }_{\mathrm{w} 1} \mathrm{X}_{\mathrm{w}}+\omega_{\mathrm{w}}>0 \\ 0 & \text { otherwise }\end{cases}
$$

A similar set of equations can be written for transfers with the husband's parents:

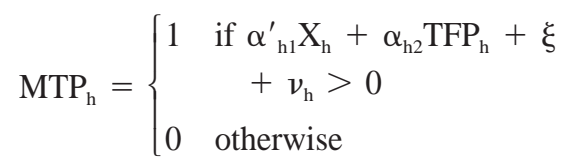

$$
\begin{aligned}
& \ln \mathrm{A}_{\mathrm{MTP}_{\mathrm{h}}}=\beta^{\prime}{ }_{\mathrm{h} 1} \mathrm{X}_{\mathrm{h}}+\beta_{\mathrm{h} 2} \operatorname{TFP}_{\mathrm{h}}+\lambda+\mu_{\mathrm{h}} \\
& \operatorname{TFP}_{h}= \begin{cases}1 & \text { if } \alpha^{\prime}{ }_{h 1} X_{h}+\omega_{h}>0 \\
0 & \text { otherwise }\end{cases}
\end{aligned}
$$

In these models, the heterogeneity terms $\xi$ and $\lambda$, may be freely correlated but the remaining parent specific residual components are all assumed to be independent of one another and across parents. Parallel sets of equations are estimated for receipt and amount received from the wife's and the husband's parents (MFP and $\ln \mathrm{A}_{\mathrm{MFP}}$ ) and for time transferred to the wife's and husband's parents (TTP).

The estimates of within couple (family) components of transfer behavior allow us to assess the degree of heterogeneity across couples in transfer behavior (Table 4). The highly significant correlations on the diagonal suggest that the extent of heterogeneity is considerable. In some families, transfers are more likely in all directions than in other families.

Table 5 presents the coefficients for the equations predicting the occurrence and monetary value of transfers from a couple to the parents of the wife and to the parents of the husband. The provision of transfers to the wife's parents is strongly associated with the characteristics of the husband and the wife. Transfers to the wife's parents are 


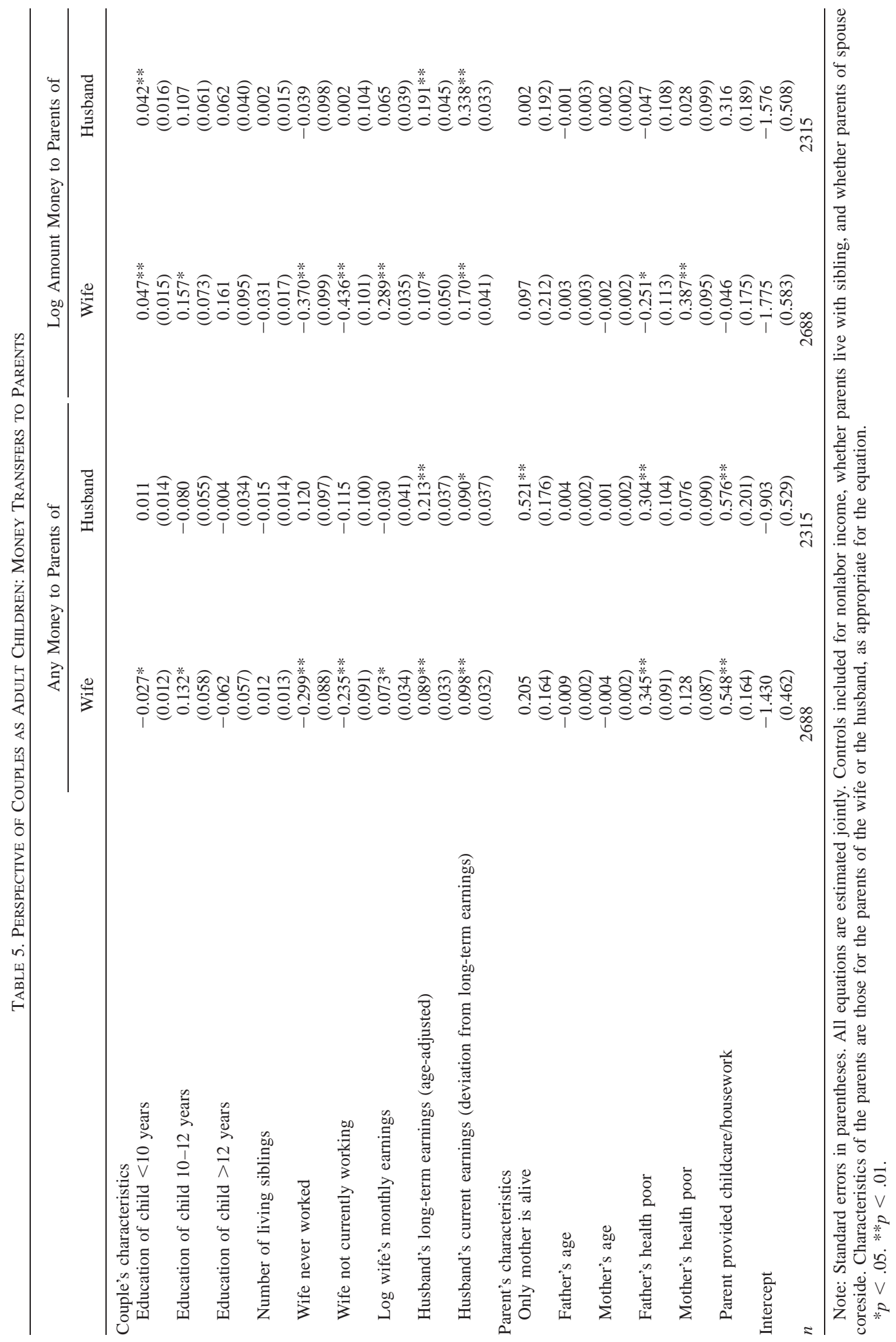


more likely when the wife is better educated, working, earning a good income, and when she is married to a man who is earning a good income. These same characteristics increase the value of the transfers that occur.

With respect to characteristics of the wife's parents, age does not affect whether the couple transfers money to them (contrary to the implications of the old age security hypothesis). A father in poor health increases the chance that a transfer occurs but decreases the value of the transfer. On the other hand, a mother in poor health is unrelated to the chance of a transfer but positively associated with the value of the transfer. These results provide some support for the insurance hypothesis. Consistent with the exchange hypothesis, transfers are significantly more likely when the wife's parents have provided the couple help in the form of time, although such help does not increase the value of transfers.

With respect to the determinants of transfers to the husband's parents, the only characteristics of the couple related to the occurrence of transfers are the husband's earnings (long term and current), which are also positively related to the amount transferred. The relative effects of the husband's long-term and current income vary across the transfer equations. Long-term income has a larger effect on whether a transfer is made than does current income but current income has a stronger effect on the amount transferred than does long-term income. It seems that long-run earnings determine the occurrence of transfers but, given a decision to transfer, the amount responds to the resources available at the time (as predicted by the insurance model).

Several characteristics of the husband's parents positively influence the couple's decision to transfer money to them. As predicted by the insurance hypothesis, transfers are more likely when the husband's mother is a widow and when the father's health status is poor. As predicted by the exchange hypothesis, transfers are more likely when parents have provided help to the couple in the form of time. Only parental provision of time affects the value of transfers the couple makes to the husband's parents.

Table 5 reveals that the provision of time to couples from their parents is an important factor in whether those couples provide money to their parents. The determinants of whether couples receive time from their parents are presented in Table 6 . With respect to time from the wife's parents, the principle determinants relate to the couple's needs. For example, the likelihood of a transfer of time is increased by the number of small children in the couple's household but decreased by number of adolescent children. Presumably a couple's needs for time from parents are higher when their children are young and lower when children reach adolescence. As the husband's earnings rise, the chance of time transfers goes down.

Our discussion of transfers from the perspective of couples as adult children has to this point focused on the provision of money to parents and receipt of time from parents. We now turn to the models of whether couples receive money from their parents and provide time transfers to them (Table 7).

The couples' characteristics play a greater role than do the parents' characteristics in predicting both the occurrence and the value of monetary transfers to couples from parents. Couples who have provided time help to the parents are more likely to receive transfers of money. Couples are much more likely to receive money from the wife's parents when the wife has never worked or is not currently working. Whether from the wife's or the husband's parents, the chance of a transfer declines as the earnings of the wife and of the husband rise, suggesting that transfers at least partly reflect needs. That a couple is less likely to receive a transfer from the wife's mother when she is a widow is further evidence to this effect. On the other hand, transfers from the wife's parents are more likely when the wife's mother's health is poor.

Relatively few characteristics of either couples or their parents are associated with the value of transfers couples receive from parents. However, the wife's educational level is positively associated with the value of transfers from her parents. The same relationship holds for the education of the husband and the transfers from his parents. The value of transfers from the wife's parents rises with her earnings and the value of transfers from the husband's parents rises with his current earnings. The final set of results (Columns 5 and 6) predict the occurrence of transfers of time from adult couples to parents. Transfers of time to the wife's parents are less likely when the wife has never worked and as the husband's earnings rise. Transfers of time to the husband's parents are more likely when the wife is educated and she does not work and less likely when the earnings of the wife and the husband are high. Generally, parental characteristics are not related to the cou- 
Table 6. Perspective of Couples as Adult Children: Time Transfers From Parents

\begin{tabular}{|c|c|c|}
\hline & \multicolumn{2}{|c|}{ Any Time Transfers From Parents o } \\
\hline & Wife & Husband \\
\hline \multicolumn{3}{|l|}{ Couple's characteristics } \\
\hline Education of child & $\begin{array}{c}0.006 \\
(0.022)\end{array}$ & $\begin{array}{c}0.013 \\
(0.022)\end{array}$ \\
\hline Education of child's spouse & $\begin{array}{c}0.025 \\
(0.019)\end{array}$ & $\begin{array}{c}-0.006 \\
(0.026)\end{array}$ \\
\hline Number of living siblings & $\begin{array}{c}-0.059 \\
(0.031)\end{array}$ & $\begin{array}{c}0.060 \\
(0.044)\end{array}$ \\
\hline Wife never worked & $\begin{array}{r}-0.510^{*} \\
(0.220)\end{array}$ & $\begin{array}{c}-0.240 \\
(0.250)\end{array}$ \\
\hline Wife not currently working & $\begin{array}{c}0.155 \\
(0.182)\end{array}$ & $\begin{array}{c}0.349 \\
(0.226)\end{array}$ \\
\hline Log wife's monthly earnings & $\begin{array}{c}-0.048 \\
(0.073)\end{array}$ & $\begin{array}{c}-0.137 \\
(0.087)\end{array}$ \\
\hline Husband's long-term earnings (age adjusted) & $\begin{array}{r}-0.162^{*} \\
(0.081)\end{array}$ & $\begin{array}{c}-0.113 \\
(0.071)\end{array}$ \\
\hline Husband's current earnings (deviation from long-term earnings) & $\begin{array}{r}-0.171^{*} \\
(0.077)\end{array}$ & $\begin{array}{c}-0.048 \\
(0.099)\end{array}$ \\
\hline \multicolumn{3}{|l|}{ Number of children at home (age in years) } \\
\hline $0-5$ & $\begin{array}{l}0.274 * * \\
(0.088)\end{array}$ & $\begin{array}{c}0.213 \\
(0.118)\end{array}$ \\
\hline $6-12$ & $\begin{array}{c}0.111 \\
(0.064)\end{array}$ & $\begin{array}{c}-0.115 \\
(0.112)\end{array}$ \\
\hline $13-18$ & $\begin{array}{r}-0.207^{*} \\
(0.091)\end{array}$ & $\begin{array}{c}-0.187 \\
(0.165)\end{array}$ \\
\hline$>18$ & -0.067 & -0.295 \\
\hline \multicolumn{3}{|l|}{ Parent's characteristics } \\
\hline Only mother is alive & $\begin{array}{c}-0.303 \\
(0.392)\end{array}$ & $\begin{array}{c}0.442 \\
(0.525)\end{array}$ \\
\hline Father's age & $\begin{array}{c}-0.005 \\
(0.006)\end{array}$ & $\begin{array}{c}0.005 \\
(0.007)\end{array}$ \\
\hline Mother's age & $\begin{array}{c}0.005 \\
(0.004)\end{array}$ & $\begin{array}{c}0.001 \\
(0.005)\end{array}$ \\
\hline Father's health poor & $\begin{array}{c}0.116 \\
(0.182)\end{array}$ & $\begin{array}{c}0.147 \\
(0.256)\end{array}$ \\
\hline Mother's health poor & $\begin{array}{c}-0.173 \\
(0.182)\end{array}$ & $\begin{array}{c}-0.166 \\
(0.258)\end{array}$ \\
\hline Intercept & $\begin{array}{r}-0.579 \\
(0.583)\end{array}$ & $\begin{array}{c}-1343 \\
(0.788)\end{array}$ \\
\hline$n$ & 2688 & 2315 \\
\hline
\end{tabular}

Note: Standard errors in parentheses. All equations jointly estimated. Controls included for total household income, whether parents live with sibling, and whether parents of spouse coreside. Characteristics of the parents are those for the parents of the wife or the husband, as appropriate for the equation.

$* p<.05 . * * p<.01$.

ple's decision to provide time help to either set of parents.

\section{DISCUSSION}

Our results suggest that no single theory completely explains the complex interactions between parents and adult children. Instead, the findings from Indonesia support the hypotheses of several models regarding motivations for transfers. Prior to discussing our results in the context of these models, however, it is important to recognize that our ability to fully test the theories is limited in two ways. First, testing for altruistically motivated transfers requires data on net transfers received over the entire life course rather than during a limited period of time. Second, our data concern only interhousehold transfers. Were we to apply similar analytical methods to data on transfers within households, different patterns might emerge.

These caveats notwithstanding, the results from Indonesia are particularly consistent with three of the models: transfers as a source of insurance, the 


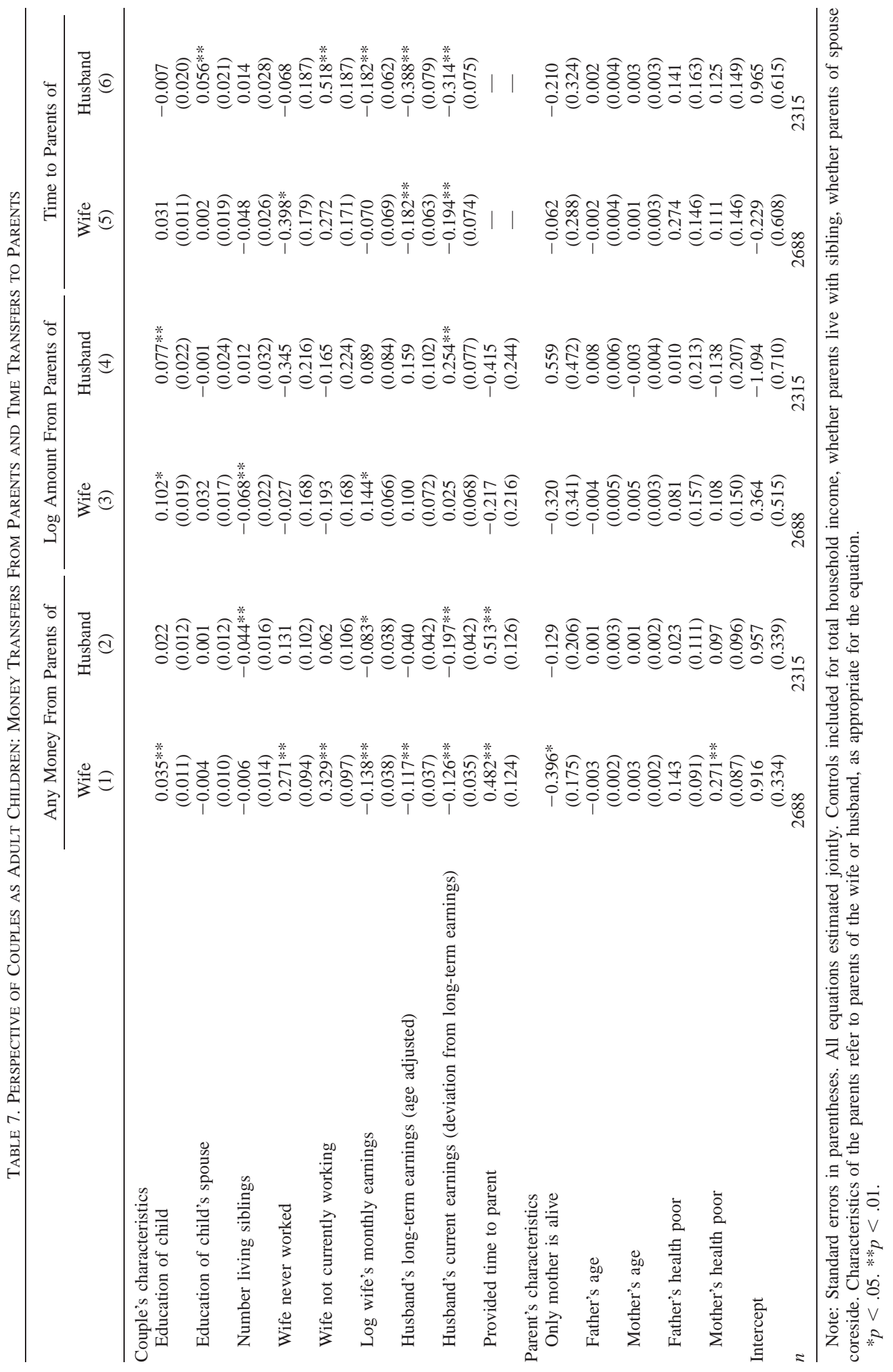


exchange of money for time, and repayments to parents for educational loans. With respect to transfers as a form of insurance, our results demonstrate that transfers are systematically related to the needs of the receiver and to the resources of the giver in ways that suggest that families use transfers to help one another out in times of need. Couples are more likely to receive transfers from their adult children when the wife is not working and when she is older. As the husband's or wife's earnings rise, reducing the need for money from adult children, the likelihood of receiving a transfer declines. Couples are less likely to make transfers to their adult children when the wife is not working, but they provide more generous transfers as the husband's earnings rise.

As adult children, couples are more likely to transfer money to widowed mothers and to fathers in poor health, and the amount transferred rises when the mother's health is poor. Couples are more likely to receive transfers of money from the husband's parents when the husband's current income is low and less likely to receive a transfer from the wife's mother if she is a widow. Couples with small children are more likely to receive time transfers from parents but couples with adolescent children are less likely to receive time transfers.

Two pieces of evidence are inconsistent with the idea that families make transfers to one another in response to times of need. Couples give less money to the wife's parents when the wife's father is in poor health, and couples are more likely to receive money from the wife's parents when the wife's mother is in poor health. The second result may reflect the practice of transferring some assets to children shortly before death, which is documented in the anthropological literature for Indonesia (Geertz, 1961; White, 1977).

In some cases, the relationship between the income levels of one generation and the amounts transferred to or from the other generation appears inconsistent with the notion that transfers are a response to need. For example, as the husband's earnings rise, so too do the amounts his offspring transfer to him and his wife. This anomaly likely reflects the fact that income levels of parents and children are correlated but in our models we can control for the income of only one generation.

Our results are also broadly consistent with the idea that money is exchanged for time. Transfers of money from one generation to another are far more likely when a transfer of time has occurred in the opposite direction. Though the evidence from the multivariate analysis supports the exchange hypothesis, the relatively low frequency of transfers of time suggests that for most families exchange of money for time does not explain transfer patterns.

A number of our results support the theory that parents finance their children's education partly as a loan repaid after the children complete school. Couples are far more likely to transfer money to their children when some of those children are enrolled in school. Additionally, the level at which children are enrolled has a strong influence on the value of the transfer that is made. In turn, couples are more likely to receive transfers from noncoresident children when those children are not in school, and the values of transfers couples receive rise with the children's levels of educational attainment. From the perspective of couples as adult children, the educational attainment of the husband and the wife are also positively associated with the value of transfers to their parents.

One result, somewhat inconsistent with the idea of parental repayment, is that couples' income levels and the wife's work status affect the occurrence and amount of transfers received from children. In a formal borrower-lender relationship the characteristics of the lender should not affect repayment by the borrower, although arrangements between parents and children may be more flexible.

We end by remarking on the similarity of the findings for Indonesia and Malaysia. In Malaysia, as in Indonesia, no one model clearly predominates. Families differ in their motivations for transfers and in the extent to which transfers are made. Notably, however, the models most consistently supported by the findings from Malaysia are the same three models that emerge most clearly from our analysis of Indonesia: transfers as a source of insurance, the exchange of money for time, and repayments to parents for educational loans.

\section{Note}

This research was supported by NIA Grants R37AG08346 and P01AG08291 and NICHD Grant P01HD28372.

\section{REFERENCES}

Becker, G. (1974). A theory of social interactions. The Journal of Political Economy, 82, 1063-1093.

Becker, G. (1991). A treatise on the family (Enlarged ed.). Cambridge, MA: Harvard University Press.

Becker, G. S., \& Tomes, N. (1976). Child endowments and the quantity and quality of children. Journal of Political Economy, 84, S142-163. 
Bengtson, V. (2001). Beyond the nuclear family: The increasing importance of multigenerational bonds (The Burgess Award Lecture). Journal of Marriage and Family, 63, 1-16.

Bernheim, D., Shleifer, A., \& Summers, L. (1985). The strategic bequest motive. Journal of Political Economy, 93, 1045-1076.

Burr, J., \& Mutchler, J. (1999). Race and ethnic variation in norms of filial responsibility among older persons. Journal of Marriage and the Family, 61, 674687.

Caldwell, J. (1976). Toward a restatement of the demographic transition theory. Population and Development Review, 2, 321-366.

Chen, A., \& Jones, G. (1989). Aging in ASEAN: Its socio-economic consequences. Singapore: Institute of Southeast Asian Studies.

Cowgill, D., \& Holmes, L. (1972). Aging and modernization. New York: Appleton-Century-Crofts.

Cox, D. (1987). Motives for private income transfers. Journal of Political Economy, 95, 508-546.

Evans, J. (1990). The economic status of older men and women in the Javanese household and the influence of this upon their nutritional level. Journal of CrossCultural Gerontology, 5, 217-242.

Geertz, H. (1961). The Javanese family: A study of kinship and socialization. Glencoe, IL: Free Press.

Goode, W. (1963). World revolution and family patterns. Glencoe, IL: Free Press.

Hermalin, A. (1997). Drawing policy lessons for Asia from research on aging. Asia-Pacific Population Journal, 12, 5-16.

Hogan, D., Eggebeen, D., \& Clogg, C. (1993). The structure of intergenerational exchanges in American families. American Journal of Sociology, 98, 14281458

Hugo, G. (1992). Aging in Indonesia: A neglected area of policy concern. In D. R. Philips (Ed.), Aging in East and Southeast Asia (Ch. 12, pp. 207-229). London: Edward Albert.

Ikkink, K., Tilburg, T., \& Knipscheer, K. (1999). Perceived instrumental support exchanges in relationships between elderly parents and their adult children: Normative and structural explanations. Journal of Marriage and the Family, 61, 831-844.

Jones, G. (1994). Marriage and divorce in Islamic South-East Asia. Singapore: Oxford University Press.

Kaplan, H. (1994). Evolutionary and wealth flows theories of fertility. Population and Development Review, 20, 753-792.

Kinsella, K. (2000). Demographic dimensions of global aging. Journal of Family Issues, 21, 541558 .

Knodel, J., \& Debavalya, N. (1997). Living arrangements and support among the elderly in South-east Asia: An introduction. Asia-Pacific Population Journal, 12, 5-16.

Knodel, J., Friedman, J., Anh, T., \& Cuong, B. (2000). Intergenerational exchanges in Vietnam: Family size, sex composition, and the location of children. Population Studies, 54, 89-104.

Lee, R. (2000). A cross-cultural perspective on intergenerational transfers and the economic life cycle. In A. Mason \& G. Tapinos (Eds.), Sharing the wealth: Demographic change and economic transfers between generations (pp. 17-56). Oxford, UK: Oxford University Press.

Lee, Y., Parish, W., \& Willis, R. (1994). Sons, daugh- ters, and inter-generational support in Taiwan. American Journal of Sociology, 99, 1010-1041.

Lillard, L. A., \& Willis, R. J. (1997a). Intergenerational educational mobility: effects of family and state in Malaysia. Journal of Human Resources, 29, 1126 1167.

Lillard, L. A., \& Willis, R. J. (1997b). Motives for intergenerational transfers: Evidence from Malaysia. Demography, 34, 115-134.

Martin, L. (1989). Living arrangements of the elderly in Fiji, Korea, Malaysia, and the Philippines. Demography, 26, 627-643.

Mahmood, T. (1992). Law and the elderly in the Islamic tradition. In D. R. Philips (Ed.), Aging in East and Southeast Asia (Ch. 16, pp. 227-235). London: Edward Albert.

Parsons, T. (1943). The kinship system of the contemporary United States. In Essays in sociological theory (pp. 177-196). Glencoe, IL: Free Press.

Preston, S. (1982). Relations between individual life cycles and population characteristics. American Sociological Review, 47, 253-264.

Ravallion, M., \& Dearden, L. (1988). Social security in a 'moral economy': An empirical analysis for Java. The Review of Economics and Statistics, 70, 36-44.

Rudkin, L. (1993). Gender differences in economic well-being among the elderly of Java. Demography, 30, 209-226.

Ruggles, S. (1987). Prolonged connections: The rise of the extended family in nineteenth century England and America. Madison, WI: University of Wisconsin.

Sievers, A. (1974). The mystical world of Indonesia. Baltimore, MD: Johns Hopkins University Press.

Stark, O. (1995). Altruism and beyond: An economic analysis of transfers and exchanges in families and groups. Cambridge, UK: Cambridge University Press.

Stecklov, G. (1997). Intergenerational resource flows in Côte d'Ivoire: Empirical analysis of aggregate flows. Population and Development Review, 23, $525-553$

White, B. (1977). Production and reproduction in a Javanese village. Unpublished doctoral dissertation. Columbia University, New York.

Willis, R. (1980). The old age security hypothesis and population growth. In T. Burch (Ed.), Demographic behavior: Interdisciplinary perspectives on decision-making (pp. 43-69). Boulder, CO: Westview Press.

Willis, R. (1982). The direction of intergenerational transfers and demographic transition: The Caldwell hypothesis reexamined. Population and Development Review, 8, S207-S234.

Wirakartakusumah, D. (1998). Household structure and the elderly in Indonesia. Unpublished manuscript, Jakarta: Demographic Institute, University of Indonesia.

Wirakartakusumah, D., Sirait, H., \& Hidayat, Z. (1997) Determinants of work and co-residence of the elderly in Indonesia (Asian Population Studies Series No. 144). Bangkok: United Nations Economic and Social Commission for Asia and the Pacific.

Wolf, D. (1991). Female autonomy, the family, and industrialization in Java. In R. L. Blumberg (Ed), Gender, family, and economy: The triple overlap (pp. 128-148). London: Sage.

World Bank. (1997). World Bank Development Report 1997: The State in a changing world. Oxford University Press. 